\title{
BRAIN TOXICOKINETICS OF PROMETRYNE IN MICE
}

\author{
Domagoj ĐIKIĆ ${ }^{1}$, Lana SAJLI ${ }^{2}$, Vesna BENKOVIĆ ${ }^{1}$, Anica HORVAT KNEŽEVIĆ ${ }^{1}$, \\ Gordana BROZOVIĆ ${ }^{3}$, Duje LISIČIĆ ${ }^{1}$, Ana MOJSOVIĆ ${ }^{4}$, and Nada ORŠOLIĆ ${ }^{1}$ \\ Department of Animal Physiology, Faculty of Science, University of Zagreb ${ }^{1}$, Forensic Centre Ivan Vučetić, \\ Ministry of Interior ${ }^{2}$, University Hospital for Tumours ${ }^{3}$, College of Applied Health Studies ${ }^{4}$, Zagreb, Croatia
}

Received in July 2009

Accepted in November 2009

\begin{abstract}
Prometryne is a methylthio-s-triazine herbicide. Significant trace amounts are found in the environment, mainly in water, soil, and food plants. The aim of this study was to establish brain and blood prometryne levels after single oral dose $\left(1 \mathrm{~g} \mathrm{~kg}^{-1}\right)$ in adult male and female mice. Prometryne was measured using the GC/MS assay at 1, 2, 4, 8, and $24 \mathrm{~h}$ after prometryne administration. Peak brain and blood prometryne values were observed $1 \mathrm{~h}$ after administration and they decreased in a time-dependent manner. Male mice had consistently higher brain and blood prometryne levels than female mice. The observed prometryne kinetics was similar to that reported for the structurally related herbicide atrazine.
\end{abstract}

KEY WORDS: blood, herbicide, nervous system, toxicity, triazine

Prometryne $\left(N, N^{\prime}\right.$-bis(1-methylethyl)-6(methylthio)-1,3,5-triazine-2,4-diamine) is used to control annual broadleaf and grass weeds in corn, carrots, parsley, peanuts, cotton, pigeon peas, alfalfa, and many other cultivated plants (1-4). Its use has been associated with increased levels in soil, water, and air, and a risk to the environment and human health (5). Prometryne is relatively persistent in water (6-8) and soil $(9,10)$. It can also be found in ambient air near production or application sites (11). Significant traces were documented in plants consumed by humans and domestic animals $(9,12-14)$ and medicinal plants treated with this herbicide (15). Trace levels of prometryne have also been reported in cow and human milk $(16,17)$. Only minimal information on the toxicokinetics of triazine herbicides in mammals has been published and the knowledge about prometryne kinetics in various organs is restricted to rats $(18,19)$. Little is known about prometryne presence in the central nervous system (CNS), but the partition coefficient $\log K_{\mathrm{ow}}=3.5$ (2) and the polarity of prometryne suggest that it might enter the CNS. The objective of this study was to see the kinetics of a single oral dose $\left(1 \mathrm{~g} \mathrm{~kg}^{-1}\right)$ of prometryne in the brain and blood of CBA mice and to compare it with previously reported kinetics of the structurally related and widely used herbicide atrazine. We also wanted to see if there were any sex-related differences in prometryne kinetics.

\section{MATERIALS AND METHODS}

\section{Animals}

For the experiment we used inbred CBA mice of both sexes $[(65 \pm 3)$ days old; male $=(23.37 \pm 1.99) \mathrm{g}$; female $=(22.25 \pm 1.14) \mathrm{g}]$ from a mouse colony of the Zagreb University Faculty of Science. The animals were fed on a pellet diet (Pliva, Zagreb, Croatia) and had free access to tap water. Light and dark exchanged 
every 12 hours. The experiment observed the Croatian animal welfare regulations (20) and the Guide for the Care and Use of Laboratory Animals (21).

\section{Treatment of experimental animals with prometryne}

The mice were randomly distributed to five experimental groups of 12 animals each, six male and six female, that received a single prometryne $\left(\mathrm{C}_{10} \mathrm{H}_{19} \mathrm{~N}_{5} \mathrm{~S}\right.$; CAS No. 7287-19-6, EPA Reg. No. 9779297; technical grade $95 \%$; Herbos, Sisak, Croatia) oral dose of $1 \mathrm{~g} \mathrm{~kg}^{-1}$ body mass in a $0.2 \mathrm{~mL}$ corn oil suspension. The control group was randomly selected from among sibling littermates and treated with the same volume of corn oil without prometryne. The control group also served to verify that the animals had not been exposed to prometryne through food or water.

The selected prometryne dose was the closest to the $1 / 3$ of mice $\mathrm{LD}_{50}$ of $3.75 \mathrm{~g} \mathrm{~kg}^{-1}$ that did not show lethal toxicity $\left(\mathrm{LD}_{10}\right)$ over 48 consecutive hours after administration, as established by pilot tests reported by EPA (1). Dosing was based previous toxicokinetic studies (22-26) that used doses higher than normally environmentally available to ensure detectable residue levels for our purposes.

Mice were weighed before oral administration of prometryne. Corn oil suspension with prometryne was given in the volume of $0.2 \mathrm{~mL}$ per animal with small adjustments to individual body mass to keep the same dose of prometryne per kilogram of body mass.

The mice were monitored for any visible clinical or behavioural signs of poisoning. They were killed by cervical dislocation one, two, four, eight, and 24 hours after prometryne administration.

The whole experiment was repeated three times.

\section{Collection of blood and brains}

Blood was collected from the heart according to the standard protocol (27). Samples of whole blood were immediately frozen $\left(-80^{\circ} \mathrm{C}\right)$ until further use, which followed within three days.

After blood collection, animals were perfused with PBS to make sure that the brain prometryne referred to brain parenchyma only. Dissected brains were placed on ice pads, weighed and immediately homogenised with constant cooling. To collect brain and blood samples we used new and thoroughly cleaned sets of instruments for each mouse to avoid any contamination with traces of prometryne from other animals.

\section{Brain and blood prometryne extraction and the GC/MS assay}

Blood and brain prometryne was analysed using the standard GC/MS assay as described earlier $(22,28)$. Briefly, to extract prometryne from blood and brain, we mixed $0.2 \mathrm{~mL}$ of water atrazine solution $(3.5 \mu \mathrm{g} \mathrm{mL})$ as internal standard and $0.15 \mathrm{~g}$ of sodium wolframate $\left(\mathrm{Na}_{2} \mathrm{WO}_{4}\right.$, Kemika, Zagreb, Croatia) with $0.5 \mathrm{~mL}$ of homogenised sample. After the salt was diluted, we added $2 \mathrm{~mL}$ of ethyl acetate/dichloromethane mixture (1:3; Sigma-Aldrich, Taufkirchen, Germany). After 5 min of vortexing and 10 min of centrifugation (6000 rpm), $1 \mathrm{~mL}$ of supernatant was transferred and desiccated. After desiccation, $0.1 \mathrm{~mL}$ of $n$-hexane (Sigma-Aldrich) was added to the sample for injection into a chromatograph Shimadzu GCMS-QP2010S with a5970 MSD model. We used a HP-5ms GC column ( $30 \mathrm{~m}, 0.25 \mathrm{~mm}$ i.d.; J\&W Agilent Technologies, USA). The injection temperature was $275^{\circ} \mathrm{C}$, with an oven temperature of $90^{\circ} \mathrm{C}$ increased to $280^{\circ} \mathrm{C}$ in 11 min. A blank sample of blood and brains from control animals was measured in parallel to make sure that the animals were not exposed to prometryne or atrazine (used as an internal standard) through food or water. To establish the calibration curve, we used 20 known concentrations of prometryne and atrazine (range: $4 \mathrm{ng} \mathrm{mL}^{-1}$ to $2000 \mathrm{ng} \mathrm{mL}^{-1}$ ) which were added to the brain and blood samples collected from control mice. Each time before measurement, we added $0.2 \mathrm{~mL}$ of internal standard for every $0.5 \mathrm{~mL}$ of real samples from animals that received prometryne, and recovery was $80 \%$ to $85 \%$. No traces of metabolites were seen.

\section{Statistical analysis}

For statistical analyses we used Statistica 5.0 software (StatSoft, Tulsa, USA). We analysed group means ( \pm standard deviation of the mean) and made multiple comparisons between groups and sexes with ANOVA. For post-hoc analysis of differences between groups we employed Scheffé's and Duncan's test. We also determined the correlation and regression coefficients between brain and blood concentrations. The level of statistical significance was set at $\mathrm{P} \leq 0.01$ and $\mathrm{P} \leq 0.05$.

\section{RESULTS}

Tables 1 and 2 show blood and brain prometryne contents, respectively. The first two rows in both tables 
Table 1 Blood prometryne concentration in mice at different time points after administration of a single oral dose (1 $\left.\mathrm{g} \mathrm{kg}^{-1}\right)$

\begin{tabular}{|c|c|c|c|c|c|c|}
\hline \multirow{2}{*}{$\begin{array}{l}\text { Sampling } \\
\text { time }\end{array}$} & \multirow{2}{*}{ Sex } & \multicolumn{5}{|c|}{ Blood prometryne concentration / $\mathrm{ng} \mathrm{mL}^{-1}$} \\
\hline & & Mean & S.D. & Median & Min. & Max. \\
\hline \multirow{3}{*}{$1 \mathrm{~h}$} & $\mathrm{~m}$ & $2765.22^{a}$ & 671.83 & 2911.83 & 1811.67 & 3486.67 \\
\hline & $\mathrm{f}$ & 1740.50 & 789.18 & 1484.00 & 1077.67 & 3246.33 \\
\hline & $\mathrm{m}+\mathrm{f}$ & $2252.86^{\mathrm{A}}$ & 880.13 & 1990.50 & 1077.67 & 3486.67 \\
\hline \multirow{3}{*}{$2 \mathrm{~h}$} & $\mathrm{~m}$ & 1144.74 & 327.25 & 1172.96 & 645.81 & 1516.88 \\
\hline & $\mathrm{f}$ & 779.72 & 436.16 & 675.31 & 384.55 & 1624.33 \\
\hline & $\mathrm{m}+\mathrm{f}$ & $962.23^{\mathrm{B}}$ & 414.11 & 850.46 & 384.55 & 1624.33 \\
\hline \multirow{3}{*}{$4 \mathrm{~h}$} & $\mathrm{~m}$ & $622.43^{a}$ & 179.86 & 663.85 & 281.35 & 799.24 \\
\hline & $\mathrm{f}$ & 403.96 & 179.54 & 363.83 & 200.81 & 737.73 \\
\hline & $\mathrm{m}+\mathrm{f}$ & $513.19^{\mathrm{C}}$ & 205.85 & 519.36 & 200.81 & 799.24 \\
\hline \multirow{3}{*}{$8 \mathrm{~h}$} & $\mathrm{~m}$ & $151.41^{\mathrm{a}}$ & 53.97 & 152.46 & 59.27 & 216.53 \\
\hline & $\mathrm{f}$ & 83.40 & 33.84 & 73.67 & 42.66 & 142.99 \\
\hline & $\mathrm{m}+\mathrm{f}$ & $117.41^{\mathrm{D}}$ & 55.73 & 116.66 & 42.66 & 216.53 \\
\hline \multirow{3}{*}{$24 \mathrm{~h}$} & $\mathrm{~m}$ & $31.54^{\mathrm{a}}$ & 12.24 & 30.26 & 14.41 & 51.78 \\
\hline & $\mathrm{f}$ & 17.91 & 6.54 & 16.55 & 11.57 & 30.19 \\
\hline & $\mathrm{m}+\mathrm{f}$ & $24.73^{\mathrm{E}}$ & 11.76 & 22.95 & 11.57 & 51.78 \\
\hline
\end{tabular}

$A-E$ A $>B>C>D>E$ at a significant level $(P \leq 0.01)$

${ }^{a}$ significantly higher $(P \leq 0.05)$ than in female mice at the same time point

Table 2 Brain prometryne mass fraction in mice at different time points after administration of a single oral dose $\left(1 \mathrm{~g} \mathrm{~kg}^{-1}\right)$

\begin{tabular}{|c|c|c|c|c|c|c|}
\hline \multirow{2}{*}{ Sampling time } & \multirow{2}{*}{ Sex } & \multicolumn{5}{|c|}{ Brain prometryne mass fraction / $\mathrm{ng} \mathrm{mg}^{-1}$} \\
\hline & & Mean & S.D. & Median & Min. & Max. \\
\hline \multirow{3}{*}{$1 \mathrm{~h}$} & $\mathrm{~m}$ & $9.502^{\mathrm{a}}$ & 2.123 & 9.767 & 6.751 & 12.416 \\
\hline & $\mathrm{f}$ & 6.256 & 2.687 & 5.115 & 3.890 & 9.887 \\
\hline & $\mathrm{m}+\mathrm{f}$ & $7.879^{\mathrm{A}}$ & 2.864 & 8.384 & 3.890 & 12.416 \\
\hline \multirow{3}{*}{$2 \mathrm{~h}$} & $\mathrm{~m}$ & 2.560 & 0.728 & 2.384 & 1.857 & 3.975 \\
\hline & $\mathrm{f}$ & 2.006 & 0.881 & 1.708 & 1.279 & 3.656 \\
\hline & $m+f$ & $2.283^{\mathrm{B}}$ & 0.823 & 2.254 & 1.279 & 3.975 \\
\hline \multirow{3}{*}{$4 \mathrm{~h}$} & $\mathrm{~m}$ & 1.188 & 0.268 & 1.142 & 0.882 & 1.577 \\
\hline & $\mathrm{f}$ & 1.015 & 0.391 & 0.826 & 0.653 & 1.577 \\
\hline & $\mathrm{m}+\mathrm{f}$ & $1.102^{\mathrm{C}}$ & 0.332 & 1.045 & 0.653 & 1.577 \\
\hline \multirow{3}{*}{$8 \mathrm{~h}$} & $\mathrm{~m}$ & 0.441 & 0.166 & 0.394 & 0.276 & 0.667 \\
\hline & $\mathrm{f}$ & 0.338 & 0.091 & 0.328 & 0.236 & 0.448 \\
\hline & $\mathrm{m}+\mathrm{f}$ & $0.389^{\mathrm{D}}$ & 0.139 & 0.346 & 0.236 & 0.620 \\
\hline \multirow{3}{*}{$24 \mathrm{~h}$} & $\mathrm{~m}$ & 0.102 & 0.031 & 0.101 & 0.051 & 0.138 \\
\hline & $\mathrm{f}$ & 0.090 & 0.024 & 0.085 & 0.065 & 0.133 \\
\hline & $\mathrm{m}+\mathrm{f}$ & $0.096^{\mathrm{E}}$ & 0.027 & 0.094 & 0.065 & 0.138 \\
\hline
\end{tabular}

$A-E A>B>C>D>E$ at a significant level $(P \leq 0.01)$

${ }^{a}$ significantly higher $(P \leq 0.05)$ than in female mice at the same time point ${ }^{a}$ significantly increased $(p \leq 0.05)$ compared to the value recorded in female mice at the same time point

bring separate results by the sexes and the third row combines these results. Table 3 is structured like the first two tables and shows correlation and regression coefficients. Figures 1 and 2 show brain-blood correlations in either sex, and Figure 3 combines them.

\section{Blood prometryne concentration}

Prometryne (in $\mathrm{ng} \mathrm{mL}^{-1}$ ) was detected in all blood samples collected over 24 hours from administration (Table 1). During that time blood concentration declined steadily. One hour after dosing, blood prometryne significantly differed $(\mathrm{P} \leq 0.01)$ between 


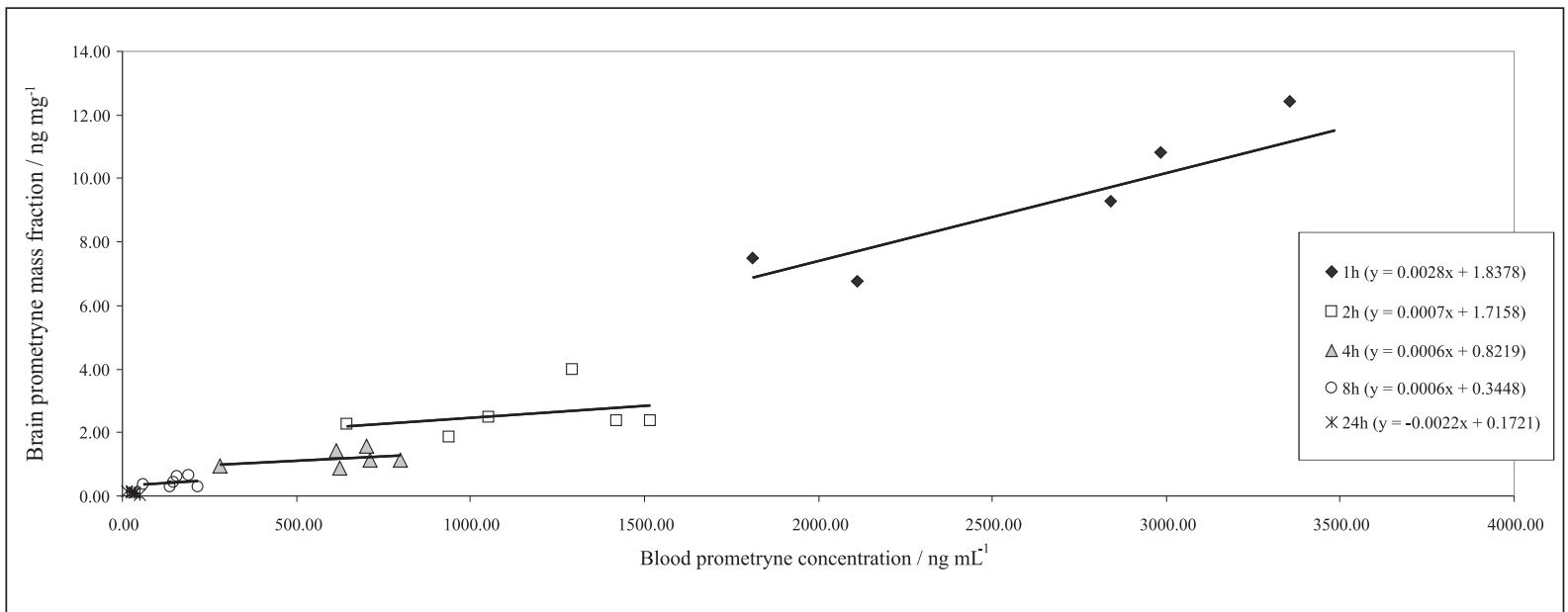

Figure 1 The relationship between brain and blood prometryne levels measured at different time points after administration of a single dose in male CBA mice

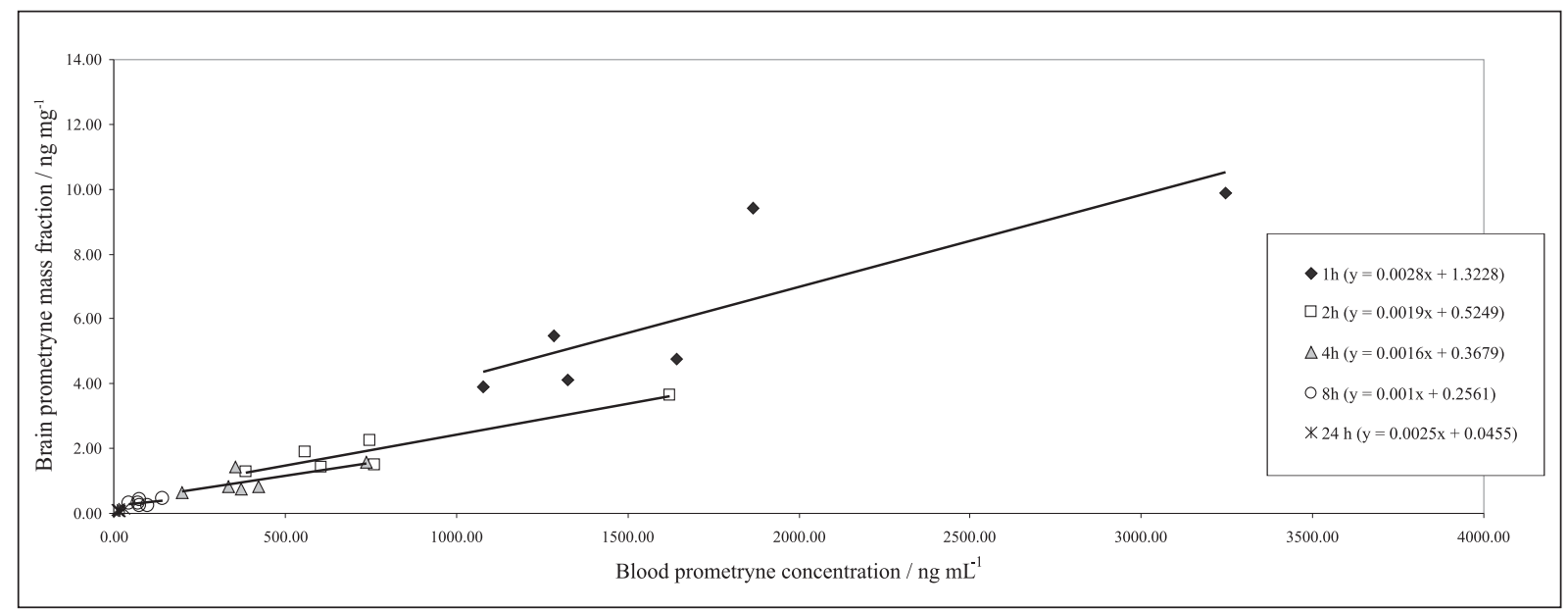

Figure 2 The relationship between brain and blood prometryne levels of prometryne measured at different time points after administration of a single dose in female CBA mice

male and female mice, as males had almost double (1.6 fold) the prometryne concentration in females. Two hours after prometryne administration, females had 1.5 times lower blood prometryne than males, but the difference was not significant. Viewed combined $(\mathrm{m}+\mathrm{f})$, prometryne concentration dropped 2.3 times from hour one to hour two post dosing $(\mathrm{P} \leq 0.01)$.

Four hours after administration, blood prometryne dropped further still (1.9 times in respect to hour two, $\mathrm{P} \leq 0.01$ and 4.4 times in respect to hour one, $\mathrm{P} \leq 0.01$ ). Again, the difference between males and females was significant (1.5 times lower in female mice, $\mathrm{P} \leq 0.01$ ). On hours eight and 24 blood prometryne rapidly dropped in all treated animals; it dropped 4.4 times between hour four and eight and 4.7 times between hours 8 and 24. The difference between the sexes was still significant $(\mathrm{P} \leq 0.01,1.8$ times lower in female mice).

\section{Prometryne in brain}

Prometryne (in $\mathrm{ng} \mathrm{m}^{-1}$ ) was detected in the brains of mice at all time points over the 24 hours after administration (Table 2). Brain prometryne mass fractions steadily declined throughout the experiment. On post-dose hour one, it was 1.5 times higher in male than in female mice $(\mathrm{P} \leq 0.01)$, which is similar to blood concentration differences between the sexes. On hour two post dose $(\mathrm{m}+\mathrm{f})$, the mass fraction dropped 3.5 times $(\mathrm{P} \leq 0.01)$. Female mice now had 1.3 times lower prometryne brain mass fraction than male mice, but the difference was not significant. Again even though female mice had 1.3 times lower brain prometryne, the 
difference was not statistically significant. On hours eight and 24, brain prometryne was very low, but still detectable. It dropped 2.8 times from hour four to eight and 4.05 times from hour eight to 24 . Female mice had 1.1 times lower brain prometryne than male mice on hour eight and 1.5 times on hour 24 post dose, but again, the difference was not statistically significant.

\section{Correlation and regression analysis}

Table 3 and Figures 1-3 show the correlation between blood and brain prometryne levels and regression coefficients. The highest significant positive correlation between brain and blood prometryne was determined in samples analysed one hour after administration. Two hours after administration, the correlation was still significant and positive in females, but not in males. When analysed together, however, the correlation was positive and almost significant $(\mathrm{P}=0.0508)$. The same was observed for samples collected four hours post dose. Again, the correlation was positive in both sexes, but significant $(\mathrm{P} \leq 0.05)$ only in female mice. The correlation for combined data was positive and significant $(\mathrm{P} \leq 0.05)$, although lower than on hour two. On hours eight and 24 post dose the correlation between brain and blood prometryne levels was no longer significant in any group.

\section{DISCUSSION}

This study was designed to simulate a normal oral exposure to prometryne from the environment (29) as previously shown by Maynard et al. (22) in rats. One of the goals was to compare the allometric differences (30-32) between rats used in the study of Maynard et al. (22) and mice which we regularly used in earlier prometryne toxicity studies $(33,34)$. One of the key documents that directed the experiment was the OECD 407 guideline for 28-day subchronic toxicity studies in rodents (21). According to this guideline, it is safe to give tested chemicals at intervals of every $24 \mathrm{~h}$ to avoid overdosing or bioaccumulation. However, Maynard et al. (22) established prometryne presence in rats even after $48 \mathrm{~h}$. While no such findings have been available for mice our results suggest that even though OECD 407 guideline recommends 24-h intervals for test chemicals, this recommendation should be taken with caution. After $24 \mathrm{~h}$, prometryne was not completely eliminated from the blood of mice (Table 1), which suggests that the remaining prometryne concentrations, however low, might build up with subchronic dosing and raise the bioavailable concentration (29).

Although prometryne was present in the blood of exposed animals, its percentage in respect to the

Table 3 Correlation and regression coefficients between brain and blood prometryne level at different sampling times following a single oral dose $\left(1 \mathrm{~g} \mathrm{~kg}^{-1}\right)$

\begin{tabular}{lccccc}
\hline Sampling time & Sex & $\mathbf{r}$ & $\mathbf{b}$ & $\mathbf{R}^{2}$ & Significance \\
\hline \multirow{3}{*}{$1 \mathrm{~h}$} & $\mathrm{~m}$ & 0.87707 & 0.00280 & 0.76930 & $\mathrm{P} \leq 0.01$ \\
& $\mathrm{f}$ & 0.83252 & 0.00280 & 0.69310 & $\mathrm{P} \leq 0.01$ \\
& $\mathrm{~m}+\mathrm{f}$ & 0.90510 & 0.00294 & 0.81940 & $\mathrm{P} \leq 0.01$ \\
\hline \multirow{3}{*}{$\mathrm{h}$} & $\mathrm{m}$ & 0.33125 & 0.00070 & 0.10970 & \\
& $\mathrm{f}$ & 0.93988 & 0.00190 & 0.88340 & $\mathrm{P} \leq 0.01$ \\
& $\mathrm{~m}+\mathrm{f}$ & 0.74860 & 0.00149 & 0.56050 & $\mathrm{P} \leq 0.05$ \\
\hline \multirow{3}{*}{$4 \mathrm{~h}$} & $\mathrm{~m}$ & 0.39374 & 0.00060 & 0.15500 & \\
& $\mathrm{f}$ & 0.73704 & 0.00160 & 0.54320 & $\mathrm{P} \leq 0.05$ \\
& $\mathrm{~m}+\mathrm{f}$ & 0.61870 & 0.00098 & 0.38230 & \\
$8 \mathrm{~h}$ & $\mathrm{~m}$ & 0.20636 & 0.00060 & 0.04260 & \\
& $\mathrm{f}$ & 0.36176 & 0.00100 & 0.13090 & \\
& $\mathrm{~m}+\mathrm{f}$ & 0.42400 & 0.00105 & 0.18000 & \\
\hline \multirow{3}{*}{$24 \mathrm{~h}$} & $\mathrm{~m}$ & -0.87960 & -0.00220 & 0.77370 & $\mathrm{P} \leq 0.01$ \\
& $\mathrm{f}$ & 0.68227 & 0.00250 & 0.46550 & \\
\hline
\end{tabular}

$r$ - correlation coefficient

$b, R^{2}$ - regression coefficients 


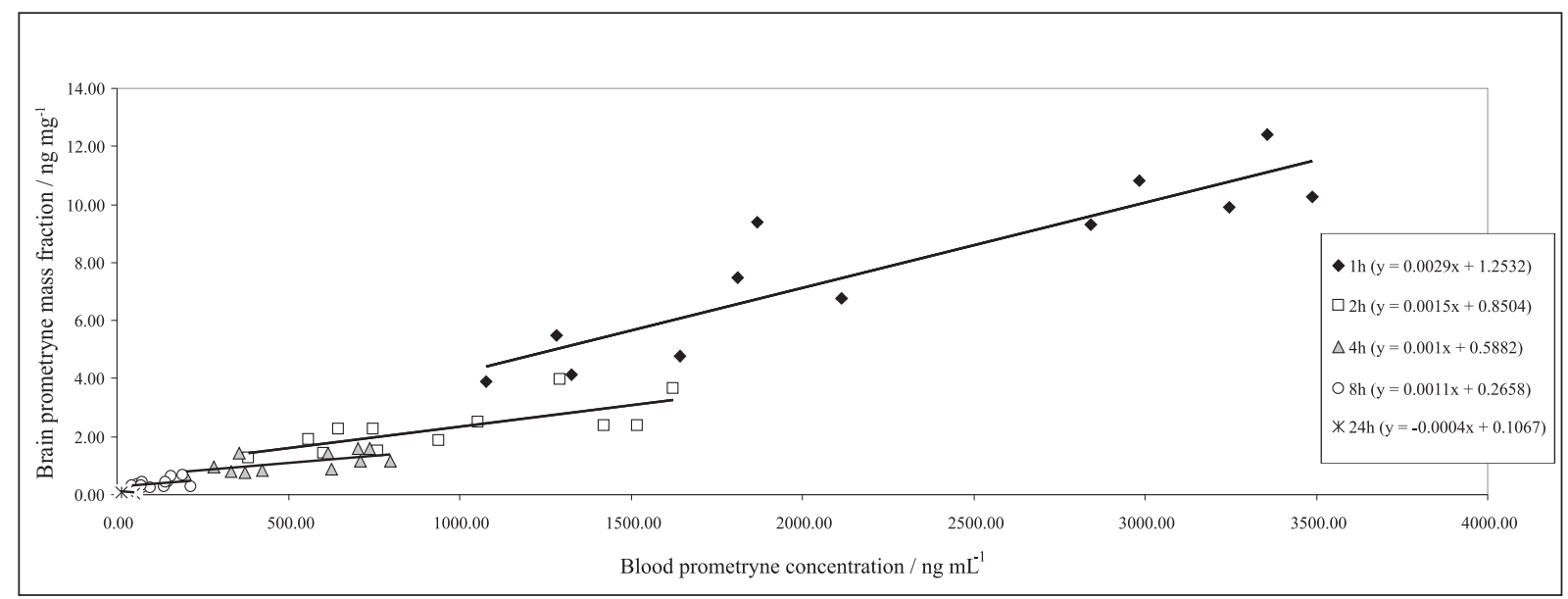

Figure 3 The relationship between brain and blood levels of prometryne measured at different time points after administration of single acute dose in male and female CBA mice combined

administered dose was relatively low. Maynard et al. (22) found that $1.2 \%$ to $1.9 \%$ of the original oral dose of prometryne was absorbed and distributed in the blood of rats. All this suggests that blood absorption of orally administered prometryne is relatively low, at least in laboratory rodents.

Data about prometryne toxicokinetics in the CNS of mammals are scarce, and our study gives an elementary view of prometryne's potential fraction and retention in the brain of mice (Table 2). Prometryne in mice brain was in even lower levels than in blood (Table 2). We selected the brain as the study organ for prometryne toxicokinetics (35) because it is well protected against xenobiotics and the hardest of organs to penetrate (36-38).

Prometryne's unpolar molecular structure and its octanol/water partition coefficient make prometryne likely to reach the brain, because brain structures are rich in lipids and have a tendency to uptake or concentrate lipofilic substances $(37,39)$. Having in mind that prometryne has low blood absorption and yet it has been traced in so distant a compartment as the brain over $24 \mathrm{~h}$, then this means that prometryne has a potential to pass through all compartments of the mammalian organism, including placenta and put embryo at risk.

To the best of our knowledge, our study is the first to show the potential of prometryne to enter mouse brain, and it is the first to analyse prometryne absorption, bioaccumulation, and elimination in neural tissue over a short time. The only records available in literature refer to the neurotoxic kinetics of atrazine, a pesticide structurally similar to prometryne $(23$,
$24,26)$. Due to similar structure, the two compounds may share some toxicological properties $(33,34)$. Our results confirm this assumption, as they correspond to the findings of Stoker and Cooper (40), who examined the toxicokinetics of atrazine in rat brain and other organs. Similar to our results for prometryne, about $0.003 \%$ of the administered dose of atrazine was found in the brain (40).

Atrazine seems to directly affect the neuroendrocrine function $(40,41)$. As our results confirm the affinity of prometryne for neural tissue, similar effects on the neuroendocrine functions are possible, but they have to be verified in future studies.

Brain and blood prometryne levels in our study decreased over $24 \mathrm{~h}$ (Tables 1,2, and 3 ) and correlated well, but not over the full range of data. This finding is expected, given the rapid distribution and/or elimination in the first two hours. Slower elimination is expected from hours 2 to 8 , with elimination halftime $\left(t_{1 / 2}\right)$ of approximately $2 \mathrm{~h}$, and even slower terminal elimination with a half life of about $8 \mathrm{~h}$. Similar decline was demonstrated for atrazine in rats (23). It could be concluded that most of prometryne absorption in mouse blood occurs within the first hour, followed by a rapid decline in concentration. This drop in the prometryne level is highly correlated between the brain and blood (Table 3 and Figure 1). The decrease rate from hour one to hour two is higher in the brain $\left(\Delta c_{m+f}=3.45 \mathrm{x} \mathrm{h}^{-1}\right)$ than in blood $\left(\Delta c_{\mathrm{m}+\mathrm{f}}=2.34 \mathrm{x} \mathrm{h}^{-1}\right)$. This points to an active process of rapid prometryne elimination from the brain, since the prometryne has to move from brain against the higher concentration in blood $(36,44,45)$. 
In our study, we also observed sex-related differences in brain and blood prometryne kinetics. Blood prometryne was significantly higher in male than in female mice at all measured times, save for hour two when it was higher, but not significantly. Brain prometryne levels were similar between males and females, except on hour one measurement when males had a significantly higher prometryne mass fraction. The differences between the sexes are particularly clear if one looks at medians (Tables 1 and 2). Higher prometryne levels (especially the peak values of the hour one) in males suggest higher absorption than in females. We also observed a different dynamic of change between the sexes. In both brain and blood, males had 1.5 times higher values on hour one. In the brain this difference was dropping towards hour 24 (1.1 times), while in blood it rose (1.76 times on hour 24). This might be explained by different body mass between the sexes $[$ male $=(23.37 \pm 1.99) \mathrm{g}$; female $=(22.25 \pm 1.14) \mathrm{g}]$ or by different fat and muscle ratio. Another explanation might be that active brain elimination occurs at the same rate regardless of the sex, while elimination mechanisms (detoxification enzymes) in blood may slightly differ between males and females (see the correlation curves in Figures 2 and 3). Therefore, neurotoxicity studies of prometryne with mice as a model organism should take into account sex differences in prometryne brain bioavailability.

Log-normal plots reveal a possible three-step elimination that could be modelled with classical pharmacokinetic models, which could greatly help researchers in designing prometryne neurotoxicity experiments. In our study, the correlation between brain and blood prometryne was stronger in female mice. Regression coefficients show slower prometryne elimination rate in male mice than in female. Regression analysis (as in Figures 1, 2, and 3) makes it possible to calculate time-course changes in blood and brain prometryne levels.

\section{Acknowledgements}

We would like to thank Mr Gordan Mršić, head of the Centre for Forensic and Toxicological Investigation "Ivan Vučetić" of the Ministry of Interior for his support and help. This study was supported by the Ministry of Science, Education and Sports of the Republic Croatia (grant no. 110-0000000-1255). Our deep thanks go to Mrs Marija Potočić and Mr Nino Vukmanić for technical support and to retired Professor Oscar P. Springer for moral support and advice.

\section{REFERENCES}

1. United States Environmental Protection Agency (US EPA). Reregistration Eligibility Decision. Prometryn [displayed 21 January 2010]. Available at http://www.epa.gov/oppsrrd1/ REDs/0467.pdf

2. Kamrin MA, Montgomery JH. Agrochemical and Pesticide Desk Reference on CD-ROM. Boca Raton (FL): Chapman and Hall/CRCnet BASE; 2000.

3. United States Environmental Protection Agency (US EPA), Integrated Risk Information System (IRIS). Prometryn (CASRN7287-19-6) [displayed 21 January 2010]. Available at http://www.epa.gov/IRIS/subst/0258.htm.

4. Amador-Ramírez MD, Mojarro-Dávila F, Velásquez-Valle R. Efficacy and economics of weed control for dry chile pepper. Crop Prot 2007;26:677-82.

5. Brusick JD. An assessment of the genetic toxicity of atrazine, relevance to human health and environmental effects. Mutat Res 1994;317:133-44.

6. Berg M, Müller SR, Schwarzenbach RP. Simultaneous determination of triazines including atrazine and their major metabolites hydroxyatrazine, desethylatrazine, and deisopropylatrazine in natural waters. Anal Chem 1995;67:1860-5.

7. Leh B, Zinko B, Narat M, Marinsek-Logar R. Monitoring of genotoxicity in drinking water using in vitro comet assay and Ames test. Food Technol Biotechnol 2005;43:139-46.

8. Hua WY, Bennett ER, Maio XS, Metcalfe CD, Letcher RJ. Seasonality effects on pharmaceuticals and s-triazine herbicides in wastewater effluent and surface water from the Canadian side of the upper Detroit River. Environ Toxicol Chem 2006;25:2356-65.

9. Fiveland TJ. Residues of linuron and prometryne in carrots and decomposition in soil in Southern and Northern Norway. Forsk Fors Landbruket 1977;28:345-63.

10. Müller F, Britz M. Regulation of prometryne in the soil. Gig Sanit 1982;8:68-70.

11. Schumann G, Garche W, Girenko D. Studies for the assessment of the herbicide prometryne in the air. Z Gesamte Hyg 1990;36:375-7.

12. Dubenetskaia MM, Patent RL, Voitik NP, Voinova IV, Krasnaia SD. Nutritive value of carrots grown using the herbicide prometryne. Vopr Pitan 1981;6:50-1.

13. Bardalaye PC, Wheeler WB. Capillary gas chromatographic determination of prometryn and its degradation products in parsley. J Assoc Anal Chem 1985;68:750-3.

14. Zhang J, Jiang W, Dong Z, Zhao S, Wie F. Simultaneous determination of triazine herbicide residues in maize by gas chromatography. Se Pu 2006;24:648-51.

15. Reifenstein H, Pank F. Triazinruckstande an arzneipflanzen [Triazine residues in medical plants, in German]. Pharmazie 1975;30:391-3

16. Krivankova L, Bocek P, Tekel J, Kovacicova J. Isotachophoretic determination of herbicides prometryne, desmetryne, terbutryne and hydroxy-derivatives of atrazine and simazine in extracts of milk. Electrophoresis 1989;10:731-4.

17. Balduini L, Matoga M, Cavalli E, Seilles E, Riethmuller D, Thomassin M, Guillaume YC. Triazinic herbicide determination by gas chromatography-mass spectrometry in breast milk. J Chromatogr B 2003;794:389-95. 
18. Larsen GL, Bakke JE. Mass spectral characterization of the glucoronide conjugates of terbutryn [2-(t-buthylamino)-4 (ethylamino)-6-methylthio)-s-triazine] metabolites from rats and goats. Biomed Mass Spectrom 1978;5:391-4.

19. Larsen GL, Bakke JE, Feil VJ. Metabolism of ${ }^{14} \mathrm{C}$ terbutryn [2-(t-buthylamino)-4 (ethylamino)-6-methylthio)-s-triazine] by rats and goats. Biomed Mass Spectrom 1978;5:382-90.

20. Zakon o dobrobiti životinja [Animal Welfare Act, in Croatian]. Narodne novine 19/1999.

21. Organization of Economic Cooperation and Developments (OECD). OECD Guideline for the testing of chemicals repeated dose 28-day oral toxicity study in rodents [displayed 21 January 2010]. Available at http://www.oecd. org/dataoecd/50/41/37477972.pdf.

22. Maynard MS, Brumback D, Itterly W, Capps T, Rose R. Metabolism of [14C] prometryn in rats. J Agric Food Chem 1999;47:3858-65.

23. McMullin TS, Brzezicki JM, Cranmer BK, Tessari JD, Andersen ME. Pharmacokinetic modeling of disposition and time-course studies with $\left[{ }^{14} \mathrm{C}\right]$ atrazine. J Toxicol Environ Health A 2003;66:941-64.

24. Filipov NM, Stewart MA, Carr RL, Sistrunk SC. Dopaminergic toxicity of the herbicide atrazine in rat striatal slices. Toxicology 2007;232:68-78.

25. Rodriguez VM, Thiruchelvam M, Cory-Slechta DA. Sustained exposure to the widely used herbicide atrazine: altered function and loss of neurons in brain monoamine systems. Environ Health Perspect 2005;113:708-15.

26. Hossain MM, Filipov NM. Alteration of dopamine uptake into rat striatal vesicles and synaptosomes caused by an in vitro exposure to atrazine and some of its metabolites. Toxicology 2008;248:52-8.

27. Green E, Georgios V, Koutos G, Heena V, Blake A, Weekes J, Hancock JM. EMPReSS: European mouse phenotyping resource for standardized screens. Bioinformatics 2005;21:2930-1.

28. Brzezicki JM, Andersen ME, Cranmer BK, Tessari JD. Quantitative identification of atrazine and its chlorinated metabolites in plasma. J Anal Toxicol 2003;27:569-73.

29. Boobis AR, Ossendorp BC, Banasiak U, Hamey PY, Sebestyen I, Moretto A. Cumulative risk assessment of pesticide residues in food. Toxicol Letrt 2008;180:137-50.

30. Adams NH, Levi P, Hodgeson E. In vitro study of the metabolism of atrazine, simazine, and terbutryn in several vertebrate species. J Agric Food Chem 1990;38:1411-7.

31. Collins JM. Inter-species differences in drug properties. Chem Biol Interact 2001;134:237-42.

32. Schneider K, Oltmanns J, Hassauer M. Allometric principles for interspecies extrapolation in toxicological risk assessment - empirical investigations. Regul Toxicol Pharmacol 2004:39:334-47.
33. Đikić D, Židovec-Lepej S, Remenar A, Bendelja K, Benković V, Horvat-Kneževic A, Brozović G, Oršolić N. Effects of prometryne on apoptosis and necrosis in thymus, lymph node and spleen in mice. Environ Toxicol Pharmacol 2009;27:1826.

34. Đikić D, Židovec-Lepej S, Remenar A, Horvat-Knežević A, Benković V, Lisičić D, Sajli L, Springer OP. The effect of prometryne on subchronically treated mice evaluated by SCGE assay. Acta Biol Hung 2009;60:35-43.

35. Andersen ME. Toxicokinetic modeling and its applications in chemical risk assessment. Toxicol Lett 2003;138:9-27.

36. DeLange CME. Potential role of ABC transporters as a detoxification system at the blood-CSF barrier. Adv Drug Deliv Rev 2004;56:1793-809.

37. Terasaki T, Ohtsuki S. Brain-to-blood transporters for endogenous substrates and xenobiotics at the blood-brain barrier. An overview of biology and methodology. NeuroRX $2005 ; 2: 63-72$

38. Liu X, Chen C, Smith BJ. Progress in brain penetration evaluation in drug discovery and development. J Pharmacol Exp Ther 2008;325:349-56.

39. Kim KB, Anand SS, Kim HJ, White CA, Bruckner JV. Toxicokinetics and tissue distribution of deltamethrin in adult sprague-dawley rats. Toxicol Sci 2008;101:197-205.

40. Stoker TE, Cooper RL. Distribution of ${ }^{14} \mathrm{C}$-atrazine following an acute lactational exposure in the Wistar rat. Reprod Toxicol 2007;23:607-10.

41. Coban A, Filipov NM. Dopaminergic toxicity associated with oral exposure to the herbicide atrazine in juvenile male C57BL/6 mice. J Neurochem 2007;100:1177-87.

42. Williamson LN, Terry AVJr, Bartlett MG. Determination of chloropyrifos and its metabolites in rat brain tissue coupledcolumn liquid chromatography/electrospray ionization mass spectrometry. Rapid Commun Mass Spectrom 2006;20:268995.

43. Prasad K, Winnik B, Thiruchelvam MJ, Buckley B, Mirochnitchenko O, Richfield EK. Prolonged toxicokinetics and toxicodynamics of paraquat in mouse brain. Environ Health Perspect 2007;115:1448-53.

44. Lesch KP, Heils A, Riederer P. The role of neurotransporters in excitotoxicity, neuronal cell death, and other neurodegenerative processes. J Mol Med 1996;74:365-78.

45. Sun H, Dai H, Shaik N, Elmquist WF. Drug efflux transporters in the CNS. Adv Drug Deliv Rev 2003;55:83-105.

46. Kusuhara H, Sugiyama Y. Active Efflux across the bloodbrain barrier. Role of the solute carrier family. 2005;2:7385.

47. Keppler D, König J. Hepatic secretion of conjugated drugs and endogenous substances. Semin Liver Dis 2000;20:265272 . 


\section{Sažetak}

\section{TOKSIKOKINETIKA PROMETRINA U MOZGU MIŠEVA}

Prometrin je metiltio-s-triazinski herbicid. Značajne količine prometrina zaostaju u tragovima u okolišu, poglavito u vodi, tlu i biljkama koje rabimo za prehranu. Cilj je rada izmjeriti količinu prometrina koja se apsorbira u mozgu i krvi nakon primijenjene akutne oralne doze ( $1 \mathrm{~g} \mathrm{~kg}^{-1}$ tjelesne mase $) \mathrm{u}$ odraslih miševa obaju spolova. Razine prometrina u mozgu i krvi izmjerene su GC/MS-om tijekom 1., 2., 4., 8. i 24. sata nakon izlaganja. Utvrđeno je da je udio prometrina koji se zadržava u živčanom tkivu relativno nizak ali detektabilan u odnosu na koncentraciju u krvi i koncentraciju primijenjene doze. Najviše koncentracije u krvi i maseni udjeli u mozgu zabilježeni su tijekom 1. sata nakon izlaganja, a s vremenom izmjerene vrijednosti značajno opadaju. Uočena je značajna razlika između mužjaka i ženki pri čemu mužjaci imaju značajno više razine prometrina u mozgu i krvi nego ženke. Opisana toksikokinetika prometrina pokazuje sličnosti s otprije opisanom i poznatom toksikokinetikom strukturalno sličnog herbicida atrazina.

KLJUČNE RIJEČI: herbicidi, krv, otrovnost, triazini, živčani sustav

\section{CORRESPONDING AUTHOR:}

Domagoj Đikić, $\mathrm{PhD}$

Department of Animal Physiology

Faculty of Science, University of Zagreb

Rooseveltov trg 6

HR-10 000 Zagreb, Croatia

E-mail:magistar_djikic1@yahoo.com 